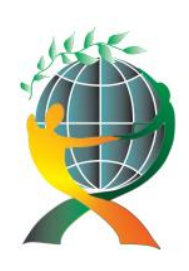

\author{
(online) $=$ ISSN $2285-3642$ \\ ISSN-L = $2285-3642$ \\ Journal of Economic Development, Environment and People \\ Volume 2, Issue 1, 2013 \\ URL: http://jedep.spiruharet.ro \\ e-mail: office jedep@spiruharet.ro
}

\title{
Green Trends in the Hotel Industry - Status and Opportunities of SERBIA
}

\author{
Bela Muhi, PhD
}

Assistant teacher, Educons University, Faculty of Business Economy, Sremska Kamenica, Vojvode Putnika bb, e-mail: muhi.bela@gmail.com

\section{Jasmina Stanković, Msc}

$\mathrm{PhD}$ candidate, teaching assistant, Educons University, Faculty of Business Economy, Sremska Kamenica, Vojvode Putnika bb, e-mail: jaca.js@gmail.com

\section{Dušan Jovanović MSc}

PhD candidate, University of Novi Sad, Faculty of Agriculture, Novi Sad, Trg Dositeja Obradovica 8, e-mail: duda.jovanovic@gmail.com

\section{Rade B. Božović MSc}

PhD candidate, University of Novi Sad, Faculty of Sciences, Department of Geography, Tourism and Hotel Management,

Novi Sad, Trg Dositeja Obradovica 3, e-mail: bozovicr@yahoo.com

\begin{abstract}
So-called "green" hotels that are trying to respect the rules of environmental pollution and reduce it to a minimum have become wide spread recently. The main principle of this trend is to use a variety of methods of responsible hotel operations, to reduce energy, water consumption and carbon dioxide emissions, to take care of the decomposition of solid waste and increase the recycling of waste materials, to use conventional detergents and other chemical agents to the lower measure and replace it by harmless "organic", to prevent or at least reduce the pollution of the environment and, wherever possible to preserve local biodiversity. In this paper, the authors provide an overview of green trends in the hotel industry with a focus on status and opportunities in Serbia.
\end{abstract}

Keywords: green hotels, environment, pollution, local biodiversity

JEL Codes: L83, M31 Q01 


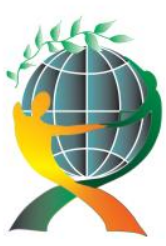

(online) = ISSN $2285-3642$

ISSN-L = $2285-3642$

Journal of Economic Development, Environment and People

Volume 2, Issue 1, 2013

URL: http://jedep.spiruharet.ro

e-mail: office jedep@spiruharet.ro

\section{Introduction}

Hotels which use "green" concept have made better business results and also made an important contribution to environmental protection (mostly in USA). The main goal of the concept of "green hotels" which has become planetary popular in the recent ten years is to reduce energy, water consumption and carbon dioxide emissions in order to prevent pollution of the environment. Ecological and sustainable hotel management has many advantages - on one hand it decreases expenses and on the other hand it represents successful marketing tool. These advantages have been recognized by big hotel chains and that is the reason to increase the number of the hotels which will adopt "green" technology. More and more hotels are trying to provide bigger number of stars that represent category of the hotel, but in the same time they give their best to ensure themselves some of the "green" certificates.

\section{Sustainable Tourism Development}

Expansive and uncontrolled tourism development over the past few decades, accompanied by many adverse environmental, social and cultural consequences imposed the need to broaden this activity in the concept of sustainable development. Sustainable development of tourism primarily depends on the ability of the environment to ensure a stable and long-term development basis. A clear demand to adapt new development strategy and a way of thinking is imposed to all the participants and stakeholders in tourism. It is important to point out the most recent expansion of the concept of sustainable tourism which is not only a need and the right of local communities to make an influence on their resources (for example threatened by tourism development), or on the other hand, tourist fashion of receptive countries. It has become a future tourism development strategy for all responsible participants in tourism (Jovicic, 2000).

It has become clear that the concept of sustainable tourism presents a new movement totally different to the tourism trends that dominated in the last decade of the $20^{\text {th }}$ century. It clearly distinguishes those activities and processes that occur as a result of a deliberate approach to understand the environment and its overall coherence and possible threats to destroy this harmony. Ultimately, a responsible tourism emerges as the understanding that tourism industry has become a threat to the environment harmony.

If tourism was a country, it would have one of the world's largest GDP's, and would consume resources at the scale of a northern developed country. The environmental impacts of tourism are tremendous. Each year, the tourism industry consumes nearly as much energy as Japan, produces the same amount of solid waste as France, and consumes as much fresh water as is contained in Lake Superior.

At the end of the $20^{\text {th }}$ and at the beginning of $21^{\text {st }}$ century influence of ecological environment has got great importance. Increased awareness of the importance of preserved and healthy environment requires an ecological approach to marketing management of tourist destinations and tour operators. The only effective approach of tourism development could be the right balance between tourism development and the protection and enhancement of the natural environment. 


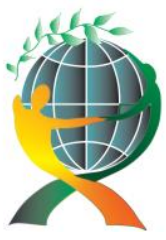

\author{
(online) $=$ ISSN $2285-3642$ \\ ISSN-L = $2285-3642$ \\ Journal of Economic Development, Environment and People \\ Volume 2, Issue 1, 2013 \\ URL: http://jedep.spiruharet.ro \\ e-mail: office jedep@spiruharet.ro
}

Nowadays a great importance is given to mutual dependence and influences of tourism development, preserved nature and economy. A new international movement is reflected on tourism demand and includes people who tend to feel the pure nature, taste organic food, buy natural materials and use renewable energy. On the other hand, global supply has made extraordinary efforts in order to minimize negative effects of tourism and to raise environmental awareness which made positive effects on tourists.

The concept of sustainable tourism development arose out of recognition of both the economic importance of tourism, as well as its realized and potential impacts. Sustainable tourism implies taking some of the principles and best practices of ecotourism and applying them to mass or conventional tourism businesses (Berno, T., Bricker, K., 2001). Today some chain hotels and large resorts, golf courses, beaches, and ski resorts and to a more limited extent, some cruise ships, have sought to "green" their operations. This is a promising trend. The ultimate goal, of course, should be to expand sustainable tourism practices to all tourism businesses, i.e., to make the entire industry environmentally, socially and economically sustainable. This process is being spurred by a growing "green" consumer movement, includes also ecotourism and sustainable tourism. It has been noted that most tourists avoid destinations with the disturbed environment. Leisure time recently takes place in a natural environment where cultural, historical, ethnographic and eco content is always welcome (Muhi, 2011).

A large number of tourist populations that participates in the global tourist migration have increased environmental awareness and desire to stay in a healthy environment, learning about flora and fauna of protected areas, etc. In order to become successful, green destinations have to be found in terms of sustainable development and improved quality of life, economic development, individual sense of well being and all that through the reduced use of nonrenewable resources and pressure on the environment and man, while preserving the integrity of creation and fostering economic growth and benefit the local community.

World Tourism Organization (UNWTO), World Travel and Tourism Council (WTTC) and the other tourism international organizations deal problems for which are responsible all entities in the tourism industry, in order to achieve the goals of sustainable development. Their goal is to establish a universal code of conduct in this area, acceptable to all participants in the development of tourism, but also to all countries. The concept of sustainable development implies a balanced economic, social and cultural development without harming the environment, which will enable future generations to develop on the same or higher level.

Planning of sustainable tourism should recognize the rights and the needs of local residents, respect their resources (physical environment), life style and the culture, but also it should give them right to make an influence on the local resources (tourist and other resources). Because of these reasons concept of sustainable tourism has become more important recently. According to many authors it has become the most important challenge and the task of tourism in the $21^{\text {st }}$ century. Sustainable tourism should be 


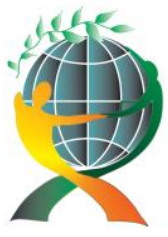

\author{
(online) $=$ ISSN $2285-3642$ \\ ISSN-L = $2285-3642$ \\ Journal of Economic Development, Environment and People \\ Volume 2, Issue 1, 2013 \\ URL: http://jedep.spiruharet.ro \\ e-mail: office jedep@spiruharet.ro
}

based on an integrated, holistic approach that includes the interconnection and cooperation of all the factors influencing development of tourism (Bakić, 2008).

\title{
3. Tourism as One of the Leading Sectors of the Global Economy
}

As a major driver of economic growth and employment worldwide, the tourism and travel sector is a critical component in the global economy. It provides economic benefits by connecting countries to international markets, encompassing people, capital, and resources. Moreover, travel and transport networks - especially air and rail - are essential economic assets for more than just transporting people; these networks also form the backbone for cargo shipments, thereby increasing regional or global economic activity. In addition, the tourism and travel sector breaks down cultural barriers and links people from various nations, while at the same time it contributes to the development of regional communities by building partnerships among local residents, organizations, and businesses. The importance of the sector worldwide is demonstrated by the liberal business environment that exists in most countries, with more than 130 World Trade Organization (WTO) members having made commitments to open up their tourist industry - more than any other service sector.

International touristic turnover in 2011 has recorded a growth of 5\% and made a new record of 970 million international touristic arrivals despite the second wave of the world economic crisis. Compared to the same period in the last year it presents 50 million more of international touristic arrivals. These results show that the international tourism continues consolidation and a growth, which has begun in 2010. No matter to all the challenges to which it was exposed. The first results of 2012 indicate that international tourism continued to show sustained growth in spite of challenging economic conditions. During the first half of 2012, international tourist arrivals grew by an estimated 5,7 percent compared to the same period of 2011, according to the June issue of the UNWTO World Tourism Barometer.

The World Tourism Organization (UNWTO) forecasts that international tourism will continue growing at the average annual rate of 4\%. UNWTO's Tourism 2020 Vision projects that domestic and international arrivals are expected to reach nearly 1.6 billion by the year 2020. Of these worldwide arrivals in 2020, 1,2 billion will be intraregional and 0,4 billion will be long-haul travellers. With the advent of e-commerce, tourism services have become one of the most traded items on the internet. 

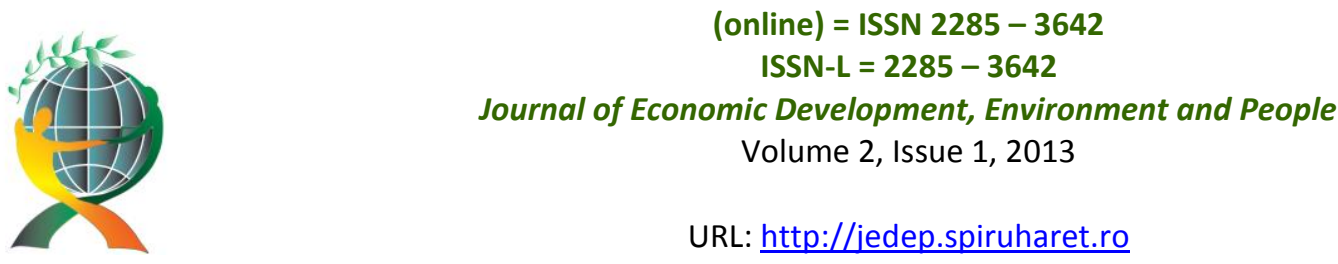

URL: http://jedep.spiruharet.ro

e-mail: office jedep@spiruharet.ro

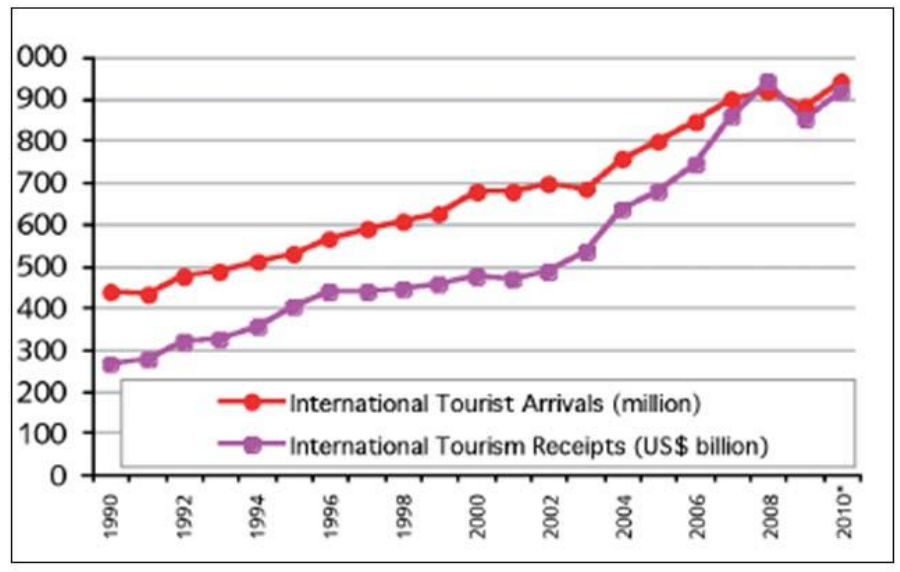

Source: World Tourism Organization (UNWTO) (2011) UNWTO Tourism Highlights

Fig. 1: International tourist arrivals and tourism receipts

\subsection{Environmental Impact of Tourism}

Tourist movements, which today are characterized by a very large number of participants (mass tourism), cause also negative effects. Primarily it is devastation of the various forms of natural and social environment. During the 60's and especially in the 70's and 80's of the last century, attention of many countries and tourist companies were strictly on the economic aspects of tourism development, i.e. its direct, indirect and multiplier effects on the economy (at macro and micro level). This produced a significant wave of criticism and focus on issues of tourism impacts on society, locals and tourists themselves. The arguments for this drew from the many examples of the negative sign in the development of tourism, such as, for example the destruction of the surrounding space (it's spending for tourism issues), derogation of the natural environment and natural attractions, the commercialization of cultural, historical and other heritage. One could make a really long list of all shapes and forms of pollution, from the most banal ones to those that significantly affect the natural and social environment. The challenge is always placed on the relationship between costs and benefits brought by tourism development in a given area. It may be noted that the concept of sustainable tourism as a form, basically, means and aspirations of the local community (or communities of wider scope) in connection with tourism development.

Therefore, there is a strong need for building tourism on the values of sustainability principles. In this way, "ecotourism", "green tourism", "sustainable tourism" is becoming a trend in the global tourism market that has a significant impact on the consciousness-tourism demand and therefore sets a new 


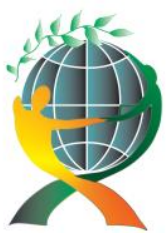

\author{
(online) $=$ ISSN $2285-3642$ \\ ISSN-L = $2285-3642$ \\ Journal of Economic Development, Environment and People \\ Volume 2, Issue 1, 2013 \\ URL: http://jedep.spiruharet.ro \\ e-mail: office jedep@spiruharet.ro
}

system of evaluation resources that determine the individual tourism products, such as flora, fauna, traditional culture, gastronomy, cultural and historical heritage, and the like.

Ecotourism has become one of the fastest-growing sectors of the tourism industry, growing annually by $10-15 \%$ worldwide. One definition of ecotourism is "the practice of low-impact, educational, ecologically and culturally sensitive travel that benefits local communities and host countries" (Honey, 2008). Responsible ecotourism includes programs that minimize the negative aspects of conventional tourism on the environment and enhance the cultural integrity of local people. Therefore, in addition to evaluating environmental and cultural factors, an integral part of ecotourism is the promotion of recycling, energy efficiency, water conservation, and creation of economic opportunities for local communities (Randall, 1987).

\title{
4. Green Hotels
}

Innovative concept of "green hotels" was presented on touristic market a few years ago. These hotels respect the rules of environmental sustainability. A big pressure which was made by ecologists, clients, staff, but also good financial moments made an attractive terrain for hotels to introduce modern and environmentally sustainable concept which among other things implies a rational consumption of energy and water, concern about waste and less pollution.. As soon as it was introduced, it was spread around the globe.

In order to keep up with the modern trends, hotel industry has introduced green hotels which respect all the ecology rules and strive to reduce the pollution of the environment. Green hotels present an example of a high quality service which provides healthy natural environment and preservation of natural beauties. The main aim of the concept of green hotels is to reduce the consumption of energy, water and the carbon dioxide emissions, to mind about the decomposition of solid waste and increase recycling of all waste materials, to use conventional detergents and other chemicals to reduce to a minimum or replace it into harmless; to prevent or at least reduce environmental pollution and, where possible, preserve local biodiversity.

Hotels which have successfully introduced this new concept (among all the countries worldwide, the biggest number of green hotels is in USA) have made better business results and a significant contribution to the environmental protection. For instance, some of the principles of green hotel involve the moment when guest leaves the room and doesn't use some of the room facilities and at that moment lights, air-condition and television turn off automatically; in the bathroom instead of special soaps and shampoos containers are placed so it can be supplemented, and the flow of water over the sink triggers movement and the time limit; also the towels and bed linen are not changed every day, etc. According to a survey of the Association of Green Hotels, at least $70 \%$ of guests support this concept. Research which was done by the TIA - U.S. Travel Industry Association shows that 60 million tourists, or $78 \%$ of the U.S. tourist population, would stay in green hotels despite the price. On the other hand, according to the results of the statistical agency of the European Union (Euro Barometer, 2011), one 


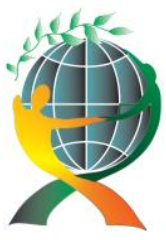

\author{
(online) $=$ ISSN $2285-3642$ \\ ISSN-L = $2285-3642$ \\ Journal of Economic Development, Environment and People \\ Volume 2, Issue 1, 2013 \\ URL: http://jedep.spiruharet.ro \\ e-mail: office jedep@spiruharet.ro
}

third of the population of the European Union would choose to travel and stay on holiday on eco destination or in a green hotel.

\title{
4.1. Some Green Hotel Samples
}

California's Grand Hotel Marriott a member of the American branch of the International Association of Green Hotels (GHA - Green Hotels Association), was awarded for the highest annual water savings, as much as 7,5 million litres per year.

Hotel Hyatt in Chicago reduced for 80 percent the amount of discarded supplies (napkins, towels, bedding, cutlery etc.). Management of the hotel ordered the employees to review carefully the items marked as "charged off". The value of what was saved was from 3,000 to 10,000 dollars per month.

Hotel Hyatt in New Zeeland made annual savings in short period by introduction of a system that shuts down lights and other electrical appliances when guest leaves a room. It cost the hotel 16,000 dollars, but it achieved annual savings of 14,000 dollars after only 14 months.

Spa resort Fairmont Sonoma in Canada reduced electricity consumption by 203,000 kilowatt-hours, "earned" 61,000 dollars per year and prevented the release into the atmosphere 144,000 pounds of carbon dioxide by replacement of 4400 ordinary light bulbs by energy saving light bulbs.

A small hotel from Toronto, which joined the city's water conservation program in the public, industrial and commercial sector, installed a commercial water softener which shortens the cycle in the washing machine. It saves daily 476,000 liters of water which is enough to supply 500 households.

The next two examples represent successful usage of ecological concept in hotel management.

\section{Bella Vista Trafoi Hotel}

A brand new design of Bella Vista Trafoi Hotel in Italian Alps was made by an Italian architect Matteo Thun. Only a huge front wall made of glass gives an idea of a human settlement. These walls made of glass keep the maximum of natural light and give beautiful views. Insulation is made of tree layers which protect the hotel object out of noise and the outside cold temperatures. Temperature inside the hotel object is moderate and pleasant. There are many environmental benefits on the Earth similar to this specific design. This specific design provides protection from the exterior weather damage, and it also maintains the flora and fauna in the region. Reducing energy consumption is a major advantage in an underground facility. Using the principles of passive design for heating and cooling is done by the heat pump on the ground floor which is supplied by the water from the local natural resources. ${ }^{1}$

\section{Naturhotel Waldklause}

One of the most visited green hotels in Austria is Naturhotel Waldklause. Despite the fact that this is one of the most expensive hotel, this hotel is usually fully booked. Modern hotel building made of

\footnotetext{
${ }^{1}$ http://www.ecofriend.com
} 


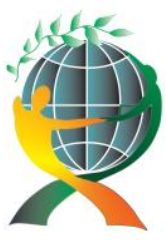

\author{
(online) $=$ ISSN $2285-3642$ \\ ISSN-L = $2285-3642$ \\ Journal of Economic Development, Environment and People \\ Volume 2, Issue 1, 2013 \\ URL: http://jedep.spiruharet.ro \\ e-mail: office jedep@spiruharet.ro
}

wooden materials is in harmony with the forest, situated near the famous Austrian touristic centre Zelden, fourhanded by the mountain heights that reach $3000 \mathrm{~m}$ above the sea levels and by a stream.

Buildings made of wooden materials are not any innovation since they have been built around the globe ever since. However, Naturhotel Waldklause is a hotel which has a capacity of 50 rooms, restaurant, bar, wellness centre and all the facilities that one luxurious hotel should have and it represents a hotel made of wood.

At the time when it was built, this hotel building was more expensive for some $30-40 \%$ since it was made of ordinary materials. Total cost was 10 million Euros. Important to mention is that the wood which was used for building wasn't ordinary wood. Wood which was used can be named "Wood of the Moon" since the trees were cut when the moon was at some stage - from full to the young, because at that stage the tree has little moisture and it cannot shrunk.

However, material cannot be the only reason for the title of the best Eco Hotel in Europe. In this hotel only organic cleaning products are used. For the heating only sawdust and wood briquettes that are purchased from a local sawmill are used, so that they can have benefits. In an ecological hotel food must be also organic. It is purchased in the nearby vicinity from the local peasants. If guests ask for the food origin, hotel staff gives them the address of the peasants, so that the guests can go to see from where the food supplies come from and purchase the food.

Of course, all this has its price. The rooms are at twice as expensive as in nearby hotels of the same category. Despite this, the hotel was sold out almost all year round. ${ }^{2}$

\title{
4.2. Eco Lodge
}

Over the last few years at many destinations a new type of accommodation called "eco lodge" has been noticed. This type of accommodation is based on the principles of ecotourism, and includes the concept of experiential education perspective, combined with the principles of environmental protection. The conclusion is that this type of accommodation provides both high quality of tourist experience and adequate environmental protection.

Eco lodge is a modest facility that meets the basic tourist needs, located in the protected areas. This type of tourist accommodation must meet the following criteria:

- Protects natural and cultural components of the environment;

- Makes a low impact on the environment while it is under the construction;

- Fits in the specific context of the environment;

- Uses alternative, sustainable means of water consumption;

- Provides careful management of waste and water waste;

- Has excellent cooperation with the local residents;

\footnotetext{
${ }^{2}$ http://www.waldklause.at
} 


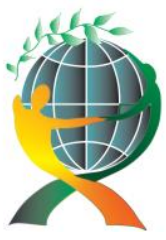

\author{
(online) $=$ ISSN $2285-3642$ \\ ISSN-L = $2285-3642$ \\ Journal of Economic Development, Environment and People \\ Volume 2, Issue 1, 2013 \\ URL: http://jedep.spiruharet.ro \\ e-mail: office jedep@spiruharet.ro
}

- Implements programs of environmental education both for employees and visitors;

- Contributes to sustainable community development through research programs.

\title{
5. Green Hotels in Serbia
}

At the Seventh International Forum of hotels and hotel managers which was organized in Belgrade with a topic "Green hotels - the basis of sustainable development of the hotel industry" it was said that the hotel managers in Serbia do not know much about the "green" technology and that only a small number of hotels in Serbia use this concept. However, the first steps have been made. Hotels in Kopaonik mountain have already arranged transportation of the oil from their fryers from the kitchen, since it is well known that the oil spill makes a real irreparable damage to the environment. A few hotels have also started using in their toilets faucets with sensors in order to avoid unnecessary spillage of water, and thereby preserve one of the most precious resources - water. Some hotels in Belgrade introduced the energy efficient lighting.

Hotel Hyatt in Belgrade has introduced a new, more economical heating system, installed sensors to control lighting in offices and other venues, as well as the frequency regulators in the kitchen and laundry room of the hotel. Hotel also introduced the recycling of all waste materials and the usage of recycled paper for all printed materials. Renewed hotel Balkan replaced coal furnace system for district heating. Good insulation in this hotel reduced to a minimum energy consumption which was previously wasted on heating and cooling.

At the moment, hotel Hyatt is the only hotel in Serbia that formed a so called "green team" which deals with this topic. This hotel has reduced the usage of the energy for $20 \%$ according to the spokesman of hotel Hyatt. New heating system HVAC was introduced together with a new switches in guest rooms, light control, sensors installed in the offices and employees in other areas as well as frequency regulators in the kitchen and laundry hotel. This way, it saves energy when the light automatically goes off when the guest leaves the room or tap water stops running after some time. Recycling of all waste materials that are used in the hotel was also introduced, as well as the usage of recycled paper for all printed materials.

Unfortunately, Serbia cannot boast of good infrastructure of hotel industry (249 officially registered hotels of which $70 \%$ have two or three star, four stars out of five hotels, while only eight hotels can boast five stars), but things are going better, which confirms the fact that in the last three years, 54 new hotels were open (hotels which have three, four, or five-star), environmental standards were introduced, the same ones which are applied in the European Union and that use elements of new "environmentally friendly" technologies.

An organization called „Environmental Ambassadors" actively promotes the concept of green hotels in Serbia. They argue that in the years to come only work with sustainable hospitality management system is economically viable, socially acceptable and safe for the environment. 


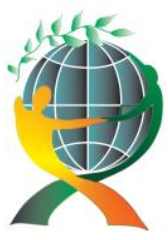

\author{
(online) $=$ ISSN $2285-3642$ \\ ISSN-L = $2285-3642$ \\ Journal of Economic Development, Environment and People \\ Volume 2, Issue 1, 2013 \\ URL: http://jedep.spiruharet.ro \\ e-mail: office jedep@spiruharet.ro
}

\title{
6. Conclusion
}

We live in a time when a great importance should be given to discussions about mutual dependence and influences of tourism development, preserved nature and economy. Ecology has become essential need of modern society and therefore it can be treated and discussed as a trend in modern business. A new international movement which is reflected on tourism demand as a primary need of modern tourists includes that people tend to spend their holidays and feel the pure and untouched nature, taste organic food, buy natural materials and use renewable energy. On the other hand, global supply has made extraordinary efforts in order to minimize negative effects of tourism and to raise environmental awareness which made positive effects on tourists that demonstrate their increased interest in the preservation of the planet.

In the past few years, all around the world one can find "green hotels" which respect all the ecology rules and strive to reduce the pollution of the environment as much as possible. The main goal of such business trend on the market is to reduce the usage of the energy and water, reduce emission of carbon dioxide and to make minimum pollution. Green hotels are the best examples how to provide a high quality service to the guests while taking them into the healthy natural environment which will preserve the natural beauties for the future generations that are about to come.

\section{References}

[1] Bakić, O., Marketing in tourism (Tourism marketing), Fabus, Sremska Kamenica, 2008, pp. 84-92

[2] Berno, T., Bricker, K., Sustainable Tourism Development: The Long Road from Theory to Practice. International Journal of Economic Development, 2001 Available from: www.spaef.com/IJED PUB/3 3/3 3 berno.html

[3] Honey, M., Ecotourism and Sustainable Development: Who Owns Paradise? (Second Ed.). Washington, DC: Island Press. 2008, pp.33

[4] Jovičić D., Tourism and the environment - the concept of sustainable tourism, Andrejevic Foundation, Belgrade, 2000

[5] Muhi, B., Katić, A., Kovačević, J., Stanković, J., Green Trends in Tourism Industry, 1st Climate Change, Economic Development, Environment and People Conference, Educons University, Novi Sad, 14-16 September, 2011

[6] Muhi, B., Kovačević, J., Stanković, J., Vojvodina as an ecological destination - positioning and development perspectives, Journal of Business Economics, Faculty of Service Business, University Educons, Vol IV - No. 1 / 2010

[7] Muhi, B., Kovačević, J., Stanković, J. Hotel Industry Going Green, II International Scientific Conference, 2nd Climate Change, Economic Developement, Environment and People Conference, sept 12-13 2012, Prešov

[8] Renewable Energy in Tourism Initiative, Best Practices in the Accommodation Sector, University of Colorado, 2008

[9] UNWTO/UNEP/WMO, Climate Change and Tourism: Responding to Global Challenges, 2007

[10] World Economic Forum , Towards a Low Carbon Travel \& Tourism Sector, World Economic Forum, 2009 


\author{
(online) $=$ ISSN $2285-3642$ \\ ISSN-L = 2285 - 3642 \\ Journal of Economic Development, Environment and People \\ Volume 2, Issue 1, 2013 \\ URL: http://jedep.spiruharet.ro \\ e-mail: office jedep@spiruharet.ro
}

[11] World Tourism Organization, UNWTO Tourism Highlights, World, 2011

[12] http://www.ecofriend.com

[13] http://www.waldklause.at 